\title{
STRATEGI PENGEMBANGANG UNIT USAHA RUMAH TEMPE DI RUMAH KEDELAI GROBOGAN (RKG)
}

\section{BUSINESS UNIT DEVELOPMENT STRATEGIES OF RUMAH TEMPE AT RUMAH KEDELAI GROBOGAN (RKG)}

\author{
Hanik Atus Sangadah dan Elisa Anggraeni*) \\ Departemen Teknologi Industri Pertanian, Fakultas Teknologi Pertanian, Institut Pertanian Bogor \\ Email: elisa_anggraeni@apps.ipb.ac.id \\ Makalah: Diterima 21 Agustus 2017; Diperbaiki 18 November 2017; Disetujui 12 Desember 2017
}

\begin{abstract}
Rumah Kedelai Grobogan (RKG) focuses on the production and dissemination of local soybean Grobogan varieties. One of its business units, Rumah Tempe, produces hygienic tempe from soybean Grobogan varieties. It has good prospect and is expected to be the driver of the development of RKG. The development of Rumah Tempe is expected to increase the use of soybean Grobogan varieties and improve RKG performance. This research aims to determine an appropriate strategy for Rumah Tempe. This research focuses on 4 stages: (1) identifying factors influencing Rumah Tempe's business development, (2) determining and selecting criteria, (3) determining alternatives for business development, (4) selecting the most preferred strategy for Rumah Tempe's business development. Analytical Hierarchy Process (AHP) was conducted to prioritize the preferred strategy. The results shows the criteria were weighted as follows: (1) New product development (0.1022), (2) Product quality (0.2747), (3) Continuity product availability (0.2938) and (4) Customer satisfaction (0.3293). Customer satisfaction is the most prioritized criteria in Rumah Tempe's business development. Alternative strategy are clasified into 4 types: prospector strategy, defender strategy, analyzer strategy, and reactor strategy. The result of the assessment shows that defender strategy is the most preferred prioritized strategy for Rumah Tempe.
\end{abstract}

Keywords: analytical hierarchy process $(A H P)$, rumah kedelai grobogan $(R K G)$, the miles and snow typology

\section{ABSTRAK}

Makalah ini membahas tentang pengembangan unit usaha Rumah Tempe di Rumah Kedelai Grobogan (RKG) yang bertanggung jawab untuk mengembangkan kedelai lokal Varietas Grobogan. Rumah Tempe merupakan salah satu unit usaha dalam RKG yang mengolah Kedelai Varietas Grobogan menjadi tempe higienis. Rumah Tempe merupakan unit usaha yang memiliki peran penting untuk mendorong penggunaan kedelai Varietas Grobogan dan berpotensi untuk dikembangkan secara komersial. Pertumbuhan Rumah Tempe akan mendorong perkembangan usaha Rumah Kedelai Grobogan. Penelitian ini bertujuan untuk menentukan prioritas strategi pengembangan unit usaha Rumah Tempe di RKG. Penelitian ini fokus pada 4 tahap: (1) identifikasi faktor berpengaruh dalam pengembangan usaha, (2) menentukan kriteria untuk pengembangan usaha, (3) menentukan alternatif untuk mengembangkan usaha, (4) memilih alternatif untuk pengembangan usaha. Analytical Hierarchy Process (AHP) digunakan untuk menentukan prioritas dengan mengandung unsur tujuan, kriteria, dan alternatif. Hasil perhitungan bobot kriteria adalah pengembangan produk $(0,1022)$, kualitas produk $(0,2747)$, kontinuitas ketersediaan produk $(0,2938)$, dan kepuasan konsumen $(0,3293)$. Kepuasan konsumen adalah kriteria prioritas dalam pengembangan usaha Rumah Tempe. Alternatif strategi diklasifikasikan pada 4 tipe yaitu strategiprospector, strategi defender, strategi analyzer dan strategi reactor. Hasil perhitungan menunjukkan bahwa strategi defender adalah prioritas strategi yang cocok diterapkan dalam pengembangan unit usaha Rumah Tempe di RKG saat ini.

Kata kunci: analytical hierarchy process (AHP), rumah kedelai grobogan (RKG), tipologi miles dan snow

\section{PENDAHULUAN}

Selama ini diketahui bahwa kedelai impor merupakan kedelai transgenik. Impor kedelai ini diperoleh dari tiga negara terbesar penghasil dan eksportir kedelai yaitu Argentina, Brazil, dan Amerika Serikat yang sebagian besar (rata-rata 87\%) bersumber dari tanaman dari benih transgenik atau organisme yang telah dimodifikasi secara genetik atau Genetically modified organisms (GMO)
(Nabradi dan Popp, 2011). Berdasarkan hal itu maka diperlukan peningkatan produktivitas kedelai lokal salah satunya Varietas Grobogan sebagai kedelai unggul non-GMO. Peningkatan produktivitas kedelai lokal ini dapat dilakukan dengan meningkatkan pengembangan inovasi produk olahan kedelai lokal namun difusi inovasi teknologi ini tidak berjalan seperti yang diharapkan. Utamanya teknologi yang menyangkut pangan, difusi teknologi menjadi lebih kompleks dikarenakan pengaruh 
berbagai faktor sosial teknologi seperti keberadaan berbagai pemangku kepentingan, kebijakan, dan praktek pertanian di lapangan (Geels et al., 2008).

Salah satu upaya yang dapat dilakukan untuk meningkatkan difusi benih kedelai lokal Varietas Grobogan adalah dengan melakukan kegiatan pengembangan unit usaha baru yang memanfaatkan kedelai lokal. Pengembangan unit usaha baru merupakan bentuk kewirausahaan institutional yang akan memunculkan aktor-aktor penggerak yang berperan sebagai katalis dalam perubahan sistemik di organisasi dan masyarakat (Leca et al.., 2008). Adanya kegiatan kewirausahaan yang memanfaatkan teknologi benih kedelai lokal akan mendorong tumbuhnya sumberdaya dan kapasitas organisasi yang penting untuk terdifusinya benih kedelai lokal dalam bentuk akumulasi pengetahuan, jejaring, maupun keahlian teknologi dan pasar dikarenakan kegiatan kewirausahaan menyebabkan terjadinya pembelajaran interaktif antar unit dengan fungsi yang berbeda dalam organisasi (Hekkert et al., 2007). Keberhasilan dalam mengembangkan produk hilir akan mendorong tumbuhnya pasar baru bagi benih lokal Varietas Grobogan karena peningkatan permintaan bahan baku kedelai lokal.

Upaya pengembangan unit usaha baru telah dilakukan dalam Rumah Kedelai Grobogan. Rumah Kedelai Grobogan merupakan unit usaha yang bergerak dari kegiatan on-farm hingga off-farm. Sebagai suatu tempat usaha, Rumah Kedelai Grobogan memiliki 5 unit usaha yang ada di dalamnya yaitu unit seed center yang bergerak dalam memproduksi benih kedelai lokal berlabel, unit Rumah Tempe yang memproduksi tempe higienis yang berbahan baku kedelai lokal Varietas Grobogan, unit learning center yang berperan dalam pengadaan program pelatihan baik untuk kegiatan on-farm maupun off-farm. Unit selanjutnya adalah unit promotion center yang berperan sebagai unit promosi berbagai produk olahan kedelai dan komoditi lain di Grobogan, dan unit resto yang memproduksi berbagai macam produk olahan kedelai maupun produk turunan dari tempe higienis.

Dari beberapa unit usaha yang ada di Rumah Kedelai Grobogan, unit usaha yang memiliki peluang untuk dikembangkan saat ini adalah unit usaha Rumah Tempe yang merupakan unit usaha hilir dari kedelai Varietas Grobogan. Unit usaha Rumah Tempe memiliki peluang untuk dikembangkan karena telah memiliki konsumen yang jelas dan memiliki keunggulan dari penggunaan bahan baku yaitu kedelai lokal Varietas Grobogan. Berkembangnya unit usaha Rumah Tempe diharapkan dapat meningkatkan penggunaan kedelai lokal Varietas Grobogan ini. Penggunaan kedelai lokal yang meningkat akan meningkatkan permintaan kedelai lokal sehingga pelaku usaha kedelai berusaha untuk memenuhi kebutuhan kedelai lokal tersebut.
Pendirian Rumah Kedelai Grobogan ini merupakan salah satu strategi untuk memanfaatkan kedelai Varietas Grobogan melalui kegiatan pengolahan. Dengan demikian, Rumah Kedelai Grobogan memiliki peranan penting dalam peningkatan penggunaan dan penyebaran kedelai Varietas Grobogan. Berdasarkan latar belakang ini, maka penelitian ini akan fokus pada penentuan strategi pengembangan unit usaha Rumah Tempe di Rumah Kedelai Grobogan. Strategi pengembangan usaha ini diharapkan mampu mendorong Rumah Tempe untuk terus bertahan dan berkembang. Peningkatan perkembangan Rumah Tempe diharapkan akan mampu meningkatkan penggunaan dan difusi kedelai Varietas Grobogan.

Penelitian ini memiliki tujuan mengidentifikasi faktor-faktor yang mempengaruhi pengembangan unit usaha Rumah Tempe, merumuskan alternatif strategi yang dapat diterapkan untuk pengembangan unit usaha Rumah Tempe, dan merekomendasikan prioritas strategi pengembangan unit usaha Rumah Tempe di Rumah Kedelai Grobogan.

\section{PENGEMBANGAN UNIT USAHA}

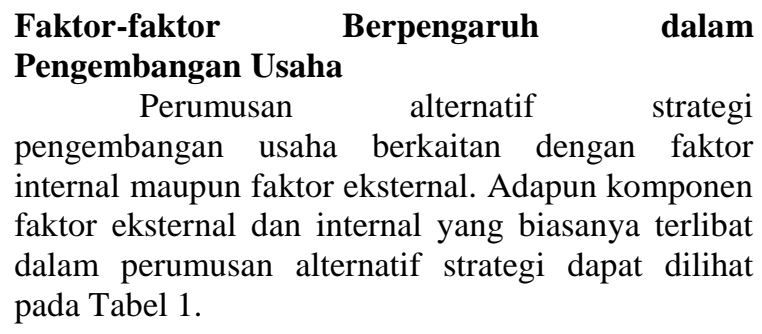

Tabel 1. Faktor-faktor dalam pengembangan usaha

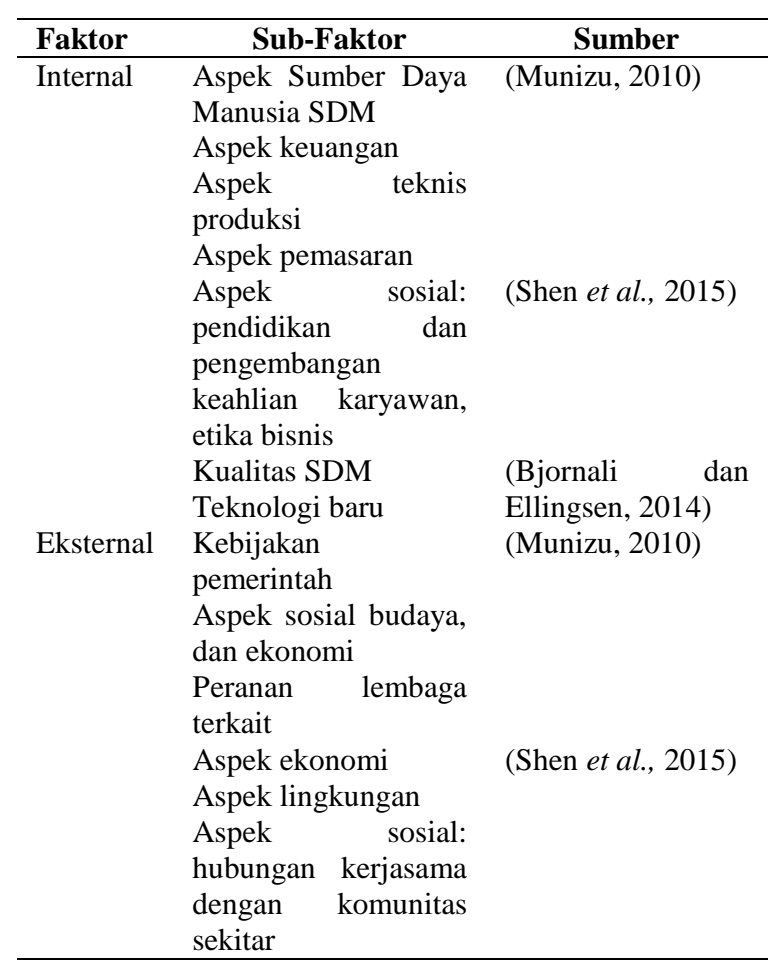


Komponen faktor yang terlibat dalam perumusan alternatif strategi pengembangan usaha biasanya terdiri dari faktor internal dan eksternal. Faktor internal terdiri dari beberapa sub-faktor diantaranya aspek sumberdaya manusia, keuangan, teknis produksi, pemasaran, teknologi dan aspek sosial. Aspek sumberdaya manusia yang berpengaruh terhadap pengembangan usaha dapat ditunjukkan dari pemilik usaha, karyawan atau pimpinan. Pengalaman pada bidang usaha sejenis memberikan pengaruh yang cukup signifikan dalam pengembangan usaha. Sementara pendidikan formal yang rendah bukan merupakan penghambat dalam memulai usaha atau untuk mengembangan usaha. Dari segi keuangan dapat dilihat dari sumber pendanaan operasional usaha dan keuntungan yang didapatkan. Jika keuangan suatu usaha sehat maka aspek keuangan tidaka akan menjadi penghambat dalam pengembangan usaha. Secara aspek teknis produksi dan operasional perusahaan, pemenuhan standar kualitas produk sesuai dengan SNI akan memberikan dukungan postif. Sama halnya dengan teknologi yang digunakan. Penggunaan teknologi modern dalam proses produksi akan mampu meningkatkan kualitas standar produk sehingga produk yang dihasilkan akan mampu memiliki nilai jual lebih tinggi. Aspek pemasaran menjadi faktor internal yang mempunyai pengaruh nyata terhadap pengembangan usaha karena keberhasilan pemasaran melalui promosi dan kegiatan lainnya mempunyai dampak yang cukup nyata terhadap pengembangan usaha. Keberhasilan pemasaran pun juga harus di dukung dengan kapasitas produksi yang dapat mendukung pemenuhan kebutuhan pasar. Aspek sosial dalam faktor internal yang dimaksud adalah tentang etika sumberdaya manusia atau hubungan yang terjalin antar karyawan dan bagaimana setiap karyawan memiliki visi dan misi yang sama dengan perusahaan sehingga mempunyai semangat untuk mewujudkan kedua hal tersebut.

Sementara faktor eksternal dalam pengembangan usaha biasanya terdiri dari aspek kebijakan pemerintah, aspek ekonomi, aspek sosial budaya, dan aspek lingkungan. Secara aspek sosial budaya adalah mengenai dampak yang ditimbulkan dengan adanya pendirian usaha. Dampak sosial budaya biasanya dapat dilihat setelah beberapa tahun usaha didirikan karena terkait dengan dampak terhadap masyarakat sekitar setelah adanya tempat usaha. Seperti apakah dengan adanya suatu usaha baru dapat meningkatkan pendapatan masyarakat sekitar. Aspek kebijakan pemerintah berpengaruh dalam pengembangan usaha adalah terkait upaya pemerintah untuk mendukung perkembangan usaha terutama untuk usaha kecil menengah. Dukungan yang biasanya dilakukan pemerintah adalah terkait kebijakan peminjaman modal usaha sehingga suatu usaha dapat mengembangkan dan memperluas usahanya.
Faktor-faktor yang berpengaruh dalam pengembangan usaha menjadi landasan dalam penentuan kriteria pengembangan usaha. Kriteria yang muncul dalam penyusunan strategi pengembangan usaha berdasarkan pada setiap subfaktor dalam faktor internal maupun faktor eksternal. Kriteria yang muncul juga dapat menjadi indikator dalam penilaian kinerja suatu usaha. Kinerja suatu usaha dapat dinilai dari pertumbuhan penjualan produk, akan tetapi pertumbuhan penjualan produk tidak berdampak langsung pada keuntungan usaha. Sumberdaya manusia yang dapat menjadi kekuatan dalam usaha adalah pengalaman atau lama berusaha pada bidang sejenis. Tingkat pendidikan sumberdaya manusia bukanlah menjadi hal penting dalam memulai atau mengembangkan usaha. Faktor terpenting dalam pengembangan usaha yang harus ada dalam sumberdaya manusia yang terlibat adalah adanya motivasi yang tinggi. Aspek operasional berkaitan dengan teknologi selama produksi yang digunakan. Penggunaan teknologi modern dan adanya jaminan kualitas seperti Standar Nasional Indonesia (SNI) atau sertifikat lainnya seperti ISO 9001 untuk sistem manajemen mutu sangat diperlukan. Aspek pasar dan pemasaran terkait erat dengan kegiatan promosi. Kegiatan promosi yang intensif mampu mendorong pengembangan usaha karena secara tidak langsung juga dapat memperluas pemasaran. Selain beberapa aspek yang telah disebutkan, aspek kebijakan pemerintah juga memiliki peranan yang cukup penting diantaranya sebagai sumber modal dan kemudahan akses wilayah tempat usaha. Aspek ekonomi, lingkungan dan sosial budaya, pengembangan usaha memiliki peran diantaranya dalam meningkatkan perekonomian masyarakat di lokasi usaha atau bahkan mampu meningkatkan pendapatan daerah (Munizu, 2010). Mariano et al. (2012) menyebutkan bahwa faktor yang dapat menjadi perhatian dalam adopsi strategi pengembangan usaha diantaranya aspek ekonomi, lingkungan, dan sosial budaya yang dapat dilihat dari perbedaan karakteristik pengguna, ketersediaan sumberdaya, peran institusi, ekstensi dan kondisi lingkungan.

\section{Strategi Pengembangan Usaha}

Pengembangan usaha merupakan suatu kegiatan yang memiliki tanggung jawab untuk mencapai tujuan dengan memiliki kebutuhan pandangan ke depan, motivasi dan kreativitas. Dalam pengembangan usaha untuk memperluas dan mempertahankan usaha maka dibutuhkan dukungan dari berbagai aspek seperti aspek teknis produksi, pemasaran, SDM, keuangan, teknologi baru dan lain-lain. Beberapa isu penting juga harus diperhatikan dalam pengembangan usaha terutama usaha berkelanjutan. Isu-isu penting yang harus diperhatikan adalah isu ekonomi terkait dengan kontribusi dalam Gross Domestic Bruto (GDB), meningkatkan penjualan dan keuntungan, isu 
lingkungan terkait manajemen lahan, penggunaan air, serta isu sosial terkait dengan pengembangan keahlian, etika bisnis dan kerjasama dengan beberapa pihak (Shen et al., 2015). Pengembangan usaha terkait erat dengan strategi inovasi, dan strategi inovasi berdasarkan pada strategi bisnis dan sasaran strategi.

Strategi pengembangan usaha berkaitan dengan bagaimana perusahaan bersaing dalam jenis usaha yang telah dipilih. Analisa dalam strategi pengembangan usaha biasanya berkaitan dengan kekuatan dan kelemahan tempat usaha serta peluang dan ancaman yang ditentukan oleh lingkungan eksternal. Terdapat empat tipologi strategi pengembangan usaha yang banyak dikenal. Keempat tipologi tersebut adalah strategi umum oleh Porter (1980), tipologi Miles dan Snow (2003), strategi eksplorasi dan eksploitasi oleh March (1991) dan Value Discipline Model oleh Treacy dan Wiersma (1993).

Aydinoglu (2007) membuat perbandingan antara keempat tipe tipologi dengan menggunakan meta-dimensi strategi kompetitif yang diusulkan oleh Campbell dan Hunt (2000) seperti tampak pada Tabel 2.

Pada Tabel 2 dapat dilihat bahwa tipologi Miles dan Snow (2003) memberikan pembedaan yang lebih jelas dibandingkan dengan tipologi yang lain pada berbagai dimensi dan antar strategi. Tipologi Miles dan Snow (2003) didasarkan pada analisa masalah fundamental dalam usaha yaitu masalah usaha, masalah operasional/teknik, dan masalah administratif. Tiga permasalahan tersebut merupakan komponen dari siklus adaptasi suatu usaha. Masalah usaha berkaitan dengan proses pemilihan produk yang mendominasi pasar. Masalah teknik berkaitan dengan pemilihan teknologi untuk produksi dan distribusi. Masalah administratif berkaitan dengan aspek kepemimpinan dalam memilih area untuk inovasi kedepannya dan aspek teknis teknologis berkaitan dengan rasionalisasi struktur dan proses dalam organisasi (Miles dan Snow, 2003).

Tabel 2. Perbandingan berbagai tipologi Strategi (Aydinoglu, 2007)

\section{Meta Dimensi dari \\ Strategi Kompetitif dari Campbell-Hunt (2000)}

\section{Tipologi Strategi (Miles dan Snow. 2003)

Strategi
Kompetitif
Generik
(Porter, 1980)

Biaya

Ekonomi biaya (Cost
Economy)
Ekonomi berfokus pada
kualitas (Focused quality
economy)
Kepemimpinan penjualan
(Sales leadership)

Kepemimpinan penjualan dan kualitas (Broad quality and sales leadership)

Kepemimpinan operasional dan Inovasi (Innovations and operational leadership) Kepemimpinan berfokus kualitas (Focus quality leadership)

$\begin{array}{cc}\text { Defender } & \text { Biaya } \\ & \\ \text { Prospector, } & \text { Biaya, } \\ \text { defender } & \text { Diferensiasi }\end{array}$

Prospector

Differensiasi

Eksplorasi

Strategi
Eksplorasi dan
Eksploitasi
(March's, 1991)

Model Value

Discipline

(Treacy dan

Wiersema, 1995)

\section{Keunggulan Operasi \\ (Operational \\ Excellence)}

Defender

Biaya

Eksploitasi

\section{Keunggulan Operasi (Operational Excellence)}

\begin{tabular}{|c|c|c|c|c|}
\hline \multirow[t]{3}{*}{$\begin{array}{l}\text { Perbandingan antar } \\
\text { strategi }\end{array}$} & Prospector & Diferensiasi & Eksplorasi & $\begin{array}{l}\text { Kepemimpinan } \\
\text { Produk }\end{array}$ \\
\hline & Analyzer & & & $\begin{array}{c}\text { Keintiman dengan } \\
\text { pengguna }\end{array}$ \\
\hline & $\begin{array}{l}\text { Defender } \\
\text { Reactor }\end{array}$ & Biaya & Eksploitasi & $\begin{array}{l}\text { Keunggulan } \\
\text { Operasional }\end{array}$ \\
\hline
\end{tabular}


Tipologi Miles dan Snow mengelompokkan strategi dalam empat golongan yaitu prospektor, defender (bertahan), analisa, dan reaktor. Tipe bertahan (defender) dapat mencapai keunggulan kompetitif dengan produk yang sudah ada di pasar, dengan tingkat ketidakpastian terendah dibanding dengan jenis lain. Tipe prospektor dapat mencapai keunggulan kompetitif dengan cara masuk ke pasar dengan produk baru yang inovatif dan merangkul teknologi baru. Tipe analisa merupakan gabungan antara tipe bertahan dan tipe prospektor. Tipe reaktor tidak dapat mencapai keunggulan yang kompetitif karena kurang jelas dan ringkas hubungan antara struktur dan strategi (Gnjidic, 2014). Adapun karakteristik umum setiap strategi dari tipologi Miles dan Snow (2003) dapat dilihat pada Tabel 3.

\section{METODE PENELITIAN}

\section{Kerangka Penelitian}

Untuk menentukan strategi prioritas pengembangan usaha, maka penelitian ini dilakukan melalui 4 tahap yang tampak pada Tabel 4 .

Tabel 3. Karakteristik Strategi dengan Tipologi Miles dan Snow

\section{Defender}

- Organisasi dengan produk-wilayah pasar terbatas

- Pimpinan organisasi biasanya ahli dalam area organisasinya yang terbatas dan tidak mencari wilayah lain di luar yang mampu menjadi peluang baru

- Organisasi memerlukan penyesuaian terhadap teknologi, struktur dan metode operasi

- Cenderung mencurahkan perhatian untuk mengembangkan efisiensi operasinya

\section{Analyzer}

- Organisasi yang beroperasi dengan 2 tipe wilayah produk-pasar, satu relatif stabil, yang lain berubahubah

- Pada area yang stabil, organisasi beroperasi secara rutin dan efisien menggunakan struktur dan proses formal dalam organisasi

- Pada area yang berubah-ubah, pimpinan melihat kompetitor dengan ide baru, dan kemudian secara cepat mengadopsi yang paling memberi harapan

Sumber: Miles dan Snow (2003)

Tabel 4. Kerangka penelitian

\begin{tabular}{ll}
\hline Tahap & Kegiatan \\
\hline Penentuan faktor-faktor & Faktor-faktor pengembangan usaha diidentifikasi dari hasil wawancara \\
pengembangan usaha & dan observasi langsung dengan responden, serta hasil dari studi \\
& literatur. Hasil identifikasi kemudian diklasifikasi dan data disajikan. \\
& Penyajian data dalam bentuk kriteria karena faktor-faktor \\
& pengembangan usaha yang didapatkan digunakan untuk menyusun \\
& kriteria pengembangan usaha. \\
Penentuan kriteria strategi & Kriteria dalam strategi pengembangan usaha disusun berdasarkan \\
pengembangan usaha & klasifikasi faktor-faktor pengembangan usaha yang telah diidentifikasi, \\
& serta berdasarkan wawancara mendalam dengan responden terkait.
\end{tabular}

- Organisasi secara kontinyu mencari peluang pasar, dan mencoba menangkap perkembangan yang ada di lingkungan

- Organisasi ini adalah kreator perubahan dan ketidakpastian dan mengharuskan kompetitor untuk merespon

- Karena kuatnya perhatian terhadap produk dan inovasi pasar, organisasi biasanya tidak begitu efisien

- Organisasi dengan pimpinan yang mengetahui perubahan dan ketidakpastian di lingkungan organisasinya tetapi tidak mampu merespon secara efektif

- $\quad$ Tipe organisasi ini kekurangan konsistensi hubungan strategi-struktur, jarang memberikan respon terhadap tekanan lingkungan
Penentuan alternatif strategi pengembangan usaha Penentuan prioritas strategi

Penentuan kriteria strategi

$\underline{2}$

Setelah kriteria pengembangan usaha tersusun, maka ditentukan alternatif strateginya. Alternatif strategi yang disusun memiliki karakteristik yang sesuai dengan instrumen peningkatan usaha yang teridentifikasi dan telah diklasifikasikan sesuai dengan karakteristik strategi pengembangan usaha.

Menentukan kriteria dan alternatif strategi prioritas dilakukan dengan metode AHP. Kriteria dan alternatif yang tersusun dalam hirarki AHP kemudian dinilai oleh pakar dan dihitung. Hasil perhitungan berupa bobot yang kemudian dapat menentukan kriteria dan alternatif prioritas. 
Penentuan Faktor- Faktor Pengembangan Usaha

Faktor-faktor yang berpengaruh dalam pengembangan usaha ditentukan berdasar hasil wawancara serta studi literatur. Faktor-faktor yang telah tersusun kemudian digunakan untuk menyusun kriteria pengembangan usaha. Penyusunan kriteria diawali dengan kegiatan mereduksi data faktorfaktor pengembangan usaha yang diperoleh. Data faktor pengembangan usaha diidentifikasi, kemudian diklasifikasikan dan diberikan identitas. Setelah data direduksi, langkah selanjutnya adalah menyajikan data (Huberman dan Miles, 1994). Hasil pengklasifikasian data faktor pengembangan usaha akan digunakan untuk menyusun kriteria pengembangan usaha.

\section{Penentuan Kriteria Strategi Pengembangan Usaha}

Kriteria merupakan bagian yang penting dalam penyusunan hirarki AHP. Menurut Saaty dan Vargas (2012) terdapat tiga prinsip utama dalam AHP yaitu menyusun hirarki, menetapkan prioritas, dan konsistensi logis. Secara sederhana, susunan hirarki AHP terdiri dari tujuan, kriteria dan alternatif. Klasifikasi faktor pengembangan usaha disajikan dan disimpulkan ke dalam kriteria pengembangan usaha. Penentuan kriteria juga berdasarkan pada kondisi usaha Rumah Kedelai Grobogan itu sendiri. Kemampuan dalam pencapaian kriteria dapat dilihat dari keunggulan yang dimiliki sehingga dapat mendorong pencapaian kriteria. Kriteria yang dapat dicapai nantinya akan mendukung tercapainya tujuan pengembangan unit usaha Rumah Tempe di Rumah Kedelai Grobogan.

\section{Penentuan Alternatif Strategi Pengembangan Usaha}

Penentuan alternatif strategi pengembangan usaha berawal dari wawancara terkait dengan instrumen kegiatan yang dapat diimplementasikan untuk mencapai kriteria. Instrumen kegiatan diidentifikasi, kemudian diklasifikasikan dan disajikan. Penyajian data untuk alternatif strategi ini berdasarkan pada strategi yang memiliki karakteristik yang sesuai dengan instrumen peningkatan kinerja yang telah diklasifikasikan. Hasil pengklasifikasian instrumen peningkatan kinerja sesuai dengan karakteristik strategi yang ada pada tipologi Miles dan Snow. Tipologi Miles dan Snow sendiri terdiri dari strategi defender, strategi prospector, strategi analyzer dan strategi reactor (Miles dan Snow, 2003). Setiap strategi memiliki karakteristik yang berbeda sehingga instrumen peningkatan kinerja penyusunnya juga berbeda.

\section{Penentuan Prioritas Strategi Dengan Metode Analitycal Hierarchy Process (AHP)}

Banyaknya kriteria dan alternatif strategi yang tersusun menyebabkan pemilihan kriteria dan alternatif strategi pengembangan usaha dilakukan dengan metode Analitycal Hierarchy Process (AHP). Metode AHP membantu dalam pengambilan keputusan untuk memilih kriteria dan alternatif strategi prioritas dalam pengembangan unit usaha Rumah Tempe di Rumah Kedelai Grobogan. Metode AHP didesain untuk memilih alternatif terbaik secara rasional dan intuitif dengan memperhatikan beberapa kriteria. Proses pengambilan keputusan dilakukan dengan perbandingan berpasangan yang kemudian digunakan untuk mengembangkan semua prioritas untuk ditentukan peringkat alternatifnya. Struktur pengambilan keputusan sederhana dari AHP terdiri dari tujuan, kriteria, dan alternatif (Saaty dan Vargas, 2012). Tujuan dalam susunan struktur hirarki strategi pengembangan usaha ditentukan berdasarkan tujuan dari pendirian Rumah Kedelai Grobogan. Kriteria didapatkan dari pengklasifikasian faktor-faktor yang berpengaruh dalam pengembangan usaha. Alternatif yang disusun sesuai dengan instrumen peningkatan usaha yang nantinya dapat dijalankan oleh Rumah Kedelai Grobogan. Penentuan prioritas alternatif didasarkan pada hasil olah data penilaian pakar.

\section{Pengumpulan Data}

Penelitian dilakukan di Rumah Kedelai Grobogan mulai dari bulan Maret sampai dengan Juli 2016. Rumah Kedelai Grobogan berlokasi di Jln. Raya Purwodadi-Solo Km 5 Krangganharjo, Toroh, Grobogan. Data yang diperoleh berupa data primer dan sekunder. Seperti terlihat pada Tabel 5.

\section{HASIL DAN PEMBAHASAN}

\section{Kriteria Strategi Pengembangan Usaha RKG}

Berdasarkan hasil wawancara, tujuan adanya usaha pengolahan kedelai lokal Grobogan adalah untuk meningkatkan nilai tambah dan konsumen kedelai lokal terutama kedelai Varietas Grobogan. Kedua tujuan tersebut kemudian diagregasi menjadi satu tujuan dalam pengembangan usaha yaitu meningkatkan konsumen produk Rumah Kedelai Grobogan. Setelah menetapkan tujuan pengembangan usaha, kemudian dilakukan analisis faktor-faktor yang mempengaruhi pengembangan usaha. Keterkaitan antar faktor pengembangan usaha kemudian digunakan untuk menyusun kriteria strategi pengembangan usaha dapat dilihat pada Tabel 6.

\section{Penentuan Kriteria Pengembangan Usaha}

Berdasarkan faktor-faktor pengembangan usaha yang diidentifikasi, terbentuk empat kriteria pengembangan usaha. Keempat kriteria pengembangan usaha yang disusun terdiri dari pengembangan produk baru, kualitas produk, kontinuitas ketersediaan produk dan kepuasan konsumen. 
Tabel 5. Data yang diperoleh dari Rumah Kedelai Grobogan

\begin{tabular}{|c|c|c|c|}
\hline Metode & Nama data & Definisi & Sumber \\
\hline \multirow{5}{*}{$\begin{array}{l}\text { Wawancara dan } \\
\text { studi literatur }\end{array}$} & Ketersediaan dan & Jumlah produksi kedelai di Kabupaten & Data dari buku statistik \\
\hline & kebutuhan kedelai di & Grobogan pada tahun 2015 serta & pertanian Kabupaten \\
\hline & Grobogan & ketersediaan dan kebutuhannya & Grobogan \\
\hline & Karakteristik kedelai & Pemaparan tentang karakteristik kedelai & Data dari bagian pangan dan \\
\hline & Varietas Grobogan & Varietas Grobogan secara keseluruhan & hortikultura \\
\hline \multirow{4}{*}{ Wawancara } & Gambaran umum & Gambaran umum keseluruhan terkait & Data dari karyawan, Kasie \\
\hline & Rumah Kedelai & kegiatan-kegiatan usaha di Rumah & Pengolahan dan Pemasaran \\
\hline & Grobogan & Kedelai Grobogan & $\begin{array}{l}\text { Hortikultura (PPH), manajer } \\
\text { RKG }\end{array}$ \\
\hline & $\begin{array}{l}\text { Faktor-faktor } \\
\text { pengembangan usaha }\end{array}$ & $\begin{array}{l}\text { Mendapatkan informasi beberapa faktor } \\
\text { terkait dengan kondisi RKG }\end{array}$ & $\begin{array}{l}\text { Data dari karyawan, Kasie } \\
\text { Pengolahan dan Pemasaran } \\
\text { Hortikultura (PPH),, manajer } \\
\text { RKG }\end{array}$ \\
\hline \multirow[t]{2}{*}{$\begin{array}{l}\text { Wawancara } \\
\text { mendalam }\end{array}$} & $\begin{array}{l}\text { Kriteria strategi } \\
\text { pengembangan usaha }\end{array}$ & $\begin{array}{l}\text { Kriteria pengembangan usaha disusun } \\
\text { dari faktor-faktor strategi pengembangan } \\
\text { usaha yang teridentifikasi }\end{array}$ & $\begin{array}{l}\text { Kasie Kasie Pengolahan dan } \\
\text { Pemasaran Hortikultura } \\
\text { (PPH), manajer RKG, } \\
\text { karyawan RKG }\end{array}$ \\
\hline & $\begin{array}{l}\text { Susunan alternatif } \\
\text { strategi pengembangan } \\
\text { usaha }\end{array}$ & $\begin{array}{l}\text { Alternatif strategi yang menjadi pilihan } \\
\text { dalam pengembangan usaha RKG }\end{array}$ & $\begin{array}{l}\text { Manajer RKG, Kasie Kasie } \\
\text { Pengolahan dan Pemasaran } \\
\text { Hortikultura (PPH), }\end{array}$ \\
\hline Kuisioner & $\begin{array}{l}\text { Penilaian bobot susunan } \\
\text { hirarki strategi } \\
\text { pengembangan usaha }\end{array}$ & $\begin{array}{l}\text { Kuisioner sebagai sarana untuk menilai } \\
\text { tingkat kepentingan kriteria dan alternatif } \\
\text { yang telah disusun }\end{array}$ & $\begin{array}{l}\text { Manajer RKG, Kasie Kasie } \\
\text { Pengolahan dan Pemasaran } \\
\text { Hortikultura (PPH), bidang } \\
\text { pangan dan hortikultura }\end{array}$ \\
\hline
\end{tabular}

Tabel 6. Keterkaitan faktor-faktor pengembangan usaha dengan kriteria

\begin{tabular}{l}
\hline Faktor-faktor \\
1. Bahan baku kedelai Varietas Grobogan \\
2. Produk berprotein banyak diminati \\
3. Produksi kedelai Varietas Grobogan \\
cukup tinggi \\
4. Perkembangan pangan yang aman \\
5. Ketersediaan sumber daya manusia
\end{tabular}

6. Proses produksi higienis

7. Harga produk

8. Peralatan produksi lebih modern

9. Produk hasil sehat dan aman

10. Lokasi usaha strategis

11. Adanya dukungan dari pemerintah

12. Kelancaran proses produksi

13. Kerjasama dengan produsen bahan baku

14. Kerjasama dengan kelompok binaan

15. Kegiatan distribusi

16. Jumlah produksi yang masih konsisten sama

17. Harga pesaing relatif lebih rendah

\section{Kriteria pengembangan produk baru}

Faktor (1), (2), (3), (4), dan (5) merupakan faktor yang mendukung untuk terciptanya pengembangan produk baru. Pengembangan produk baru merupakan faktor kritis yang mempengaruhi peningkatan pangsa pasar sebuah perusahaan (Banburry dan Mitchell, 1995). Investasi sumberdaya yang mencukupi pada pengembangan produk baru akan secara positif mempengaruhi peningkatan pangsa pasar (Zhang et al, 2009). Kriteria pengembangan produk baru berkaitan dengan kebutuhan SDM yang berkompeten, berpengalaman dan memiliki motivasi tinggi untuk menggunakan pengetahuan untuk mengembangkan produk baru dan usaha.

2. Kriteria kualitas produk

Faktor (1), (6), (7), (8), dan (9) merupakan faktor yang menyusun kriteria kualitas produk. Bahan baku yang berkualitas dan aman akan menghasilkan produk yang berkualitas pula. Produk berkualitas yang dihasilkan mampu mendorong kepercayaan konsumen karena kebutuhan produk berkualitas dapat terpenuhi. Harga produk dipengaruhi oleh harga bahan baku dan proses produksi. Kualitas bahan baku yang baik yaitu kedelai lokal nonGMO memiliki kualitas dan harga yang lebih tinggi dari kedelai impor serta diproses dengan proses yang higienis akan memengaruhi kualitas produk yang dihasilkan.

3. Kriteria kontinuitas ketersediaan produk

Faktor (3), (10), (11), (12), (13), (14), dan (15) adalah faktor yang menyusun kriteria kontinuitas ketersediaan produk. Lokasi usaha yang dekat dengan sumber bahan baku tidak menyulitkan dalam upaya pengadaan bahan baku. Kriteria ini adalah satu upaya untuk mencapai tujuan pengembangan usaha. Kriteria (16) dan Kriteria (17) juga merupakan faktor yang mempengaruhi ketersediaan produk. Peningkatan jumlah produksi akan secara posotif mempengaruhi peningkatan ketersediaan produk. Harga pesaing yang relatif lebih rendah juga mempengaruhi ketersediaan produk. Jika harga lebih rendah, maka dapat mempengaruhi ketertarikan pada produk sehingga pada jangka lama akan berpengaruh secara negatif pada ketersediaan produk. 


\section{Faktor-faktor}

18. Memiliki merk dagang produk sendiri

19. Pelayanan

20. Tim pelatih ahli dibidangnya

21. Perkembangan teknologi informasi

22. Kegiatan promosi

23. Memperluas pasar

\section{Keterkaitan dengan kriteria}

\section{Kriteria kepuasan konsumen}

Faktor (1), (18), (19), dan (20) akan menyusun kriteria kepuasan konsumen. Kepuasan konsumen biasanya berkaitan dengan pelayanan. Konsumen yang merasa puas dengan produk yang dipasarkan akan cenderung kembali lagi untuk membeli produk yang sama. Hal ini mampu meningkatkan konsumen yang membutuhkan produk terutama jika konsumen yang puas secara langsung memberikan informasi kepada konsumen yang lainnya. Bahan baku yang merupakan kedelai lokal varietas Grobogan memberikan kepuasan konsumen karena merupakan kedelai non-GMO dan bukan kedelai impor. Merk dagang tempe yang dimiliki RKG dapat memberikan rasa puas kepada konsumen karena konsumen mengetahui bahwa tempe yang dijual terbuat dari bahan baku berkualitas. Sementara tim pelatih yang ahli akan memberikan kepuasan kepada konsumen yang memanfaatkan jasa pelatihan kegiatan on-farm maupun off-farm karena pelatih yang memberikan materi adalah para ahli dibidangnya. Faktor (21), (22), dan (23) Adanya perkembangan teknologi dapat dimanfaatkan sebagai ajang untuk mempromosikan produk RKG sehingga lebih dikenal luas. Semakin luas produk dikenal dapat meningkatkan peminat dan kepuasan pelanggan karena kemudahan akses ke produk.

\begin{abstract}
Keempat kriteria diperoleh dari hasil wawancara dan dengan mempertimbangkan faktorfaktor yang telah dideskripsikan dan diklasifikasikan. Munizu (2010) menyatakan bahwa terdapat beberapa hal yang harus diperhatikan dalam pengembangan usaha yaitu terkait aspek SDM, aspek operasional, aspek pasar dan pemasaran, aspek kebijakan pemerintah serta aspek ekonomi, sosial dan budaya. Aspek pasar dan pemasaran menjadi dasar dalam merumuskan kriteria kepuasan konsumen, kontinuitas ketersediaan produk, kualitas produk serta pengembangan produk baru. Pengembangan produk baru dapat menjadi kriteria bagaimana usaha mampu beradaptasi dengan pasar. Kualitas produk dan kontinuitas ketersediaan produk akan mendukung terciptanya kepuasan konsumen sehingga dari tingkat jumlah konsumen produk dapat diketahui bagaimana proses pemasaran dan luas pasar dari produk. Aspek operasional terkait dengan proses produksi sehingga dapat disusun kriterianya adalah adanya kualitas produk yang terjamin dengan digunakannya alat yang berteknologi dan proses produksi yang higienis. Aspek sosial, ekonomi, dan budaya menjadi dasar dalam menentukan kriteria kontinuitas ketersediaan produk. Produk akan terus tersedia jika bahan baku produk juga tersedia sehingga kegiatan ekonomi dapat terus berjalan. Bahan baku dapat terus tersedia ketika pelaku usaha bahan baku merasa puas secara sosial (masyarakat memperoleh keuntungan sosial), ekonomi (memberikan keuntungan ekonomi) dan budaya (masyarakat menerima keberadaan usaha dalam sistem sosialnya) sehingga tetap dapat terus menekuni kegiatan usahanya.
\end{abstract}

\section{Perumusan Alternatif Strategi Pengembangan Usaha}

Setelah menentukan kriteria pengembangan usaha, kemudian mengidentifikasi instrumen peningkatan kinerja untuk menyusun alternatif strategi pengembangan usaha. Penentuan alternatif strategi dilakukan dengan terlebih dahulu mengetahui beberapa karakteristik strategi pengembangan usaha yang sesuai dengan instrumen peningkatan kinerja tersebut. Karakteristik strategi yang sesuai dengan instrumen yang telah diidentifikasi adalah strategi dari Tipologi Miles dan Snow. Penyusunan alternatif strategi sesuai dengan instrumen yang teridentifikasi dapat dilihat pada Tabel 7.

Strategi pengembangan usaha yang dijelaskan Tabel 7 sesuai dengan Tipologi Miles dan Snow yang memberikan alternatif-alternatif strategi bersaing dengan tujuan agar perusahaan dapat menerapkan strategi tersebut pada waktu dan situasi yang tepat dengan terlebih dahulu memahami posisi perusahaan dalam persaingan (Miles dan Snow, 2003).

\section{Analisis Pengambilan Keputusan dengan Metode AHP}

Berdasarkan wawancara dan pengamatan yang telah dilakukan dengan pihak terkait, dari faktor-faktor yang berpengaruh dalam pengembangan usaha Rumah Kedelai Grobogan dihasilkan 4 kriteria utama strategi pengembangan usaha yaitu pengembangan produk baru, kualitas produk, kontinuitas ketersediaan produk dan kepuasan konsumen. Alternatif strategi pengembangan usaha terdiri dari 4 tipe yaitu prospector, defender, analyzer, dan reactor. Susunan hirarki AHP dalam strategi pengembangan usaha Rumah Kedelai Grobogan dapat dilihat pada 
Gambar 1. Setelah struktur hirarki tersusun, maka dilanjutkan dengan penilaian kuisioner oleh responden.

Responden yang digunakan dalam penentuan strategi pengembangan usaha RKG terdiri dari 3 orang yaitu Kasie Pengolahan dan pemasaran Hasil Pertanian (PPH), manajer Rumah Kedelai Grobogan (RKG), serta bagian pangan dan hortikultura. Kasie Pengolahan dan Pemasaran Hasil Pertanian dan manajer Rumah Kedelai Grobogan sebagai pengambil keputusan. Pakar lainnya adalah pegawai bagian Pangan dan Hortikultura yang mengetahui kondisi produksi kedelai Varietas Grobogan di Kabupaten Grobogan. Data hasil analisis 3 pakar kesemuanya memiliki nilai konsistensi rasio $(\mathrm{CR})<0,10$. Hal ini menunjukkan bahwa hasil penilaian pakar konsisten atau ketidak konsistenan masih dapat diterima dengan nilai CR < 0,10 . Hasil penilaian gabungan untuk penentuan bobot kriteria pengembangan usaha dapat dilihat pada Tabel 8 .

Berdasarkan hasil pengolahan Tabel 8 dapat diketahui bahwa nilai eigen vector paling tinggi yaitu 0,3293 adalah kriteria 4 (kepuasan konsumen). Kepuasan konsumen merupakan kriteria yang memiliki nilai eigen vector paling tinggi, hal ini menunjukkan bahwa kriteria pengembangan usaha yang memiliki bobot untuk dipenuhi terlebih dahulu adalah kepuasan konsumen. Nilai CI hasil pembobotan kriteria sebesar 0,0063 sehingga perlu dilakukan pengecekan nilai $\mathrm{CR}$ dan nilai CRnya sebesar $0,0070<0,10$. Nilai $\mathrm{CR}<0,10$ menandakan bahwa hasil penilaian pakar memiliki nilai inkonsistensi yang masih dapat diterima

Tabel 7. Susunan alternatif strategi pengembangan usaha

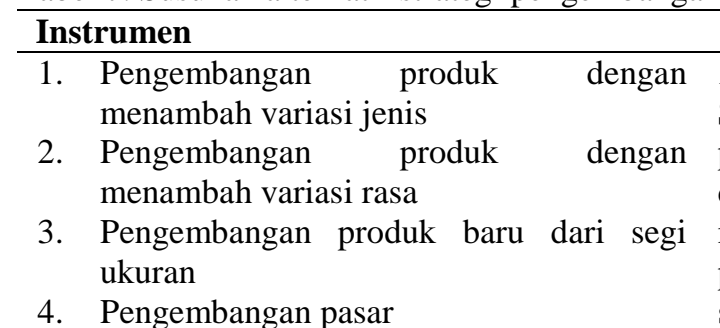

Strategi

Pengembangan pasa

$\begin{array}{ll}\text { 5. Sistem penjaminan kualitas } & 2 . \quad \text { Defender } \\ \text { 6. Penyeleksian bahan baku dan pengawasan } & \text { Strategi yang lebih mementingkan kestabilan usaha dalam }\end{array}$

1. Prospector

Strategi yang lebih mementingkan inovasi produk dan pengembangan pasar. Intrumen (1), (2), (3), dan (4) sesuai dengan karakteristik prospector. Bila RKG akan menggunakan instrumen tersebut maka kegiatan pengembangan usaha yang dilakukan termasuk dalam tipe strategi prospector.

Pengembangan produk olahan kedelai lokal Grobogan selain tempe adalah dengan mengolahnya menjadi susu kedelai yang dapat dikembangkan variasi rasanya seperti rasa buah. Selain itu juga dapat mengembangkan olahan lainnya seperti tahu, kembang tahu atau kecap. produksi secara berkala

7. Pemanfaatan sistem quality control dalam proses

8. Meningkatkan kontrol atas distribusi

9. Perencanaan produksi yang tepat

10. Penguatan kerjasama dengan kelompok binaan

11. Proses transaksi dengan pelanggan (langsung/delivery order) pasar yang sudah ada sehingga usaha akan kontinu berjalan. Salah satu hal yang dapat menjaga kestabilan pasar adalah menciptakan kepuasan konsumen. Instrumen (5), (6), (7), (8), (9), (10), dan (11) dapat mendorong terciptanya kestabilan usaha dengan mempertahankan eksistensi produk yang telah dimiliki serta mengefisiensikan seluruh sumber daya yang dimiliki. Sistem quality control perlu dilakukan dalam setiap proses produksi terutama terkait dengan CCP proses produksi. Dari sistem quality control perlu didukung dengan sistem penjaminan kualitas yang terkait dengan perencanaan dan kegiatan sistematik yang diperlukan untuk memberikan suatu keyakinan yang memadai bahwa suatu produk telah memenuhi persyaratan mutu atau standart mutu produk.

3. Analyzer

Strategi yang menggabungkan antara strategi prospector dan defender, strategi ini berinovasi dalam produk baru serta tetap menjaga kestabilan pasar yang sudah dimiliki. Kegiatan yang dapat dilakukan untuk tipe strategi ini adalah gabungan beberapa instrumen dari instrumen kegiatan prospector dan defender. Instrumen kegiatan yang termasuk menyusun strategi ini adalah instrumen (1), (2), (3), (4), (8), dan (9)

12. Pengembangan produk baru sesuai dengan produk baru pesaing

Strategi yang baru bergerak ketika ada tindakan dari lingkungan luar terutama pesaing. Strategi ini akan melakukan respon terhadap tindakan yang dilakukan oleh lingkungan luar. Strategi ini biasanya kurang konsisten dan stabil dalam merespon perubahan lingkungan. Instrumen kegiatan yang sesuai dengan karakteristik strategi ini 


\begin{tabular}{ll}
\hline Instrumen & Strategi \\
\hline & adalah instrumen (4) dan (12). \\
\hline
\end{tabular}

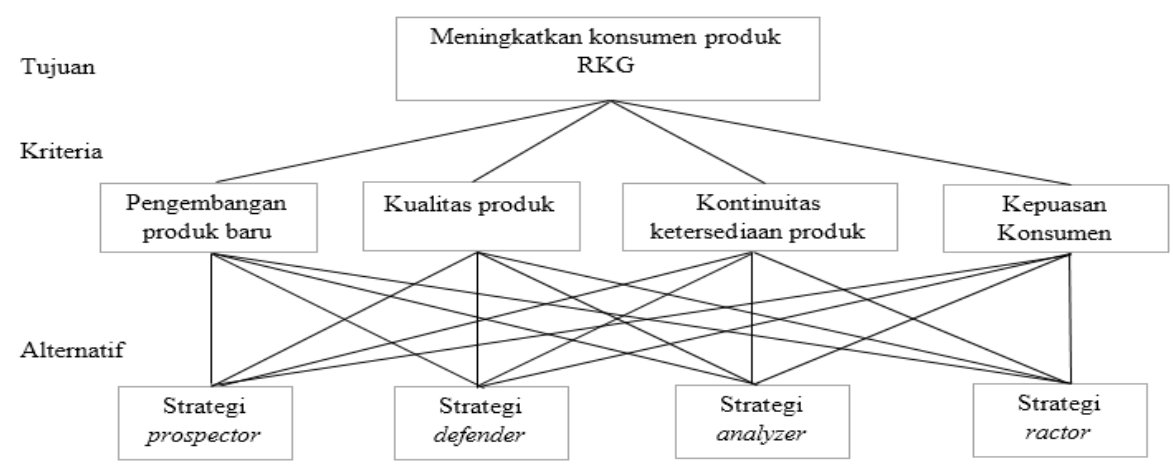

Gambar 1. Struktur Hirarki AHP

Tabel 8. Hasil pembobotan kriteria untuk pengembangan usaha RKG

\begin{tabular}{lccrrr}
\hline Kriteria & K1 & K2 & K3 & K4 & Eigen vector \\
\hline K1 & 1,0000 & 0,3333 & 0,3625 & 0,3333 & 0,1022 \\
K2 & 3,0000 & 1,0000 & 1,0000 & 0,6934 & 0,2747 \\
K3 & 2,7589 & 1,0000 & 1,0000 & 1,0000 & 0,2938 \\
K4 & 3,0000 & 1,4422 & 1,0000 & 1,0000 & $\mathbf{0 , 3 2 9 3}$ \\
\hline Jumlah & 9,7589 & 3,7756 & 3,3625 & 3,0267 & 1,0000 \\
\hline Principal eigen value $(\lambda$ max) & & & & 4,0189 \\
Consistency index $(\mathrm{CI})$ & & & & 0,0063 \\
Consistency ratio $(\mathrm{CR})$ & & & & 0,0070 \\
\hline Kerangar
\end{tabular}

Keterangan:

K1 : pengembangan produk baru

K2 : kualitas produk

K3 : kontinuitas ketersediaan produk

K4 : kepuasan konsume

Tabel 9. Hasil pembobotan alternatif terhadap setiap kriteria

\begin{tabular}{lrrrrr}
\hline K/A & \multicolumn{1}{l}{ K1 } & \multicolumn{1}{c}{ K2 } & \multicolumn{1}{c}{ K3 } & \multicolumn{1}{c}{ K4 } & \multicolumn{1}{c}{ Bobot kriteria } \\
\hline A1 & 0,2965 & 0,2262 & 0,2056 & 0,2047 & 0,1022 \\
A2 & 0,2056 & 0,2987 & 0,2965 & 0,2953 & 0,2747 \\
A3 & 0,2716 & 0,2262 & 0,2263 & 0,2047 & 0,2938 \\
A4 & 0,2263 & 0,2489 & 0,2716 & 0,2953 & 0,3293 \\
\hline
\end{tabular}

Keterangan:

A1 : strategi prospector

A2 : strategi defender

A3 : strategi analyzer

A4 : strategi reactor 


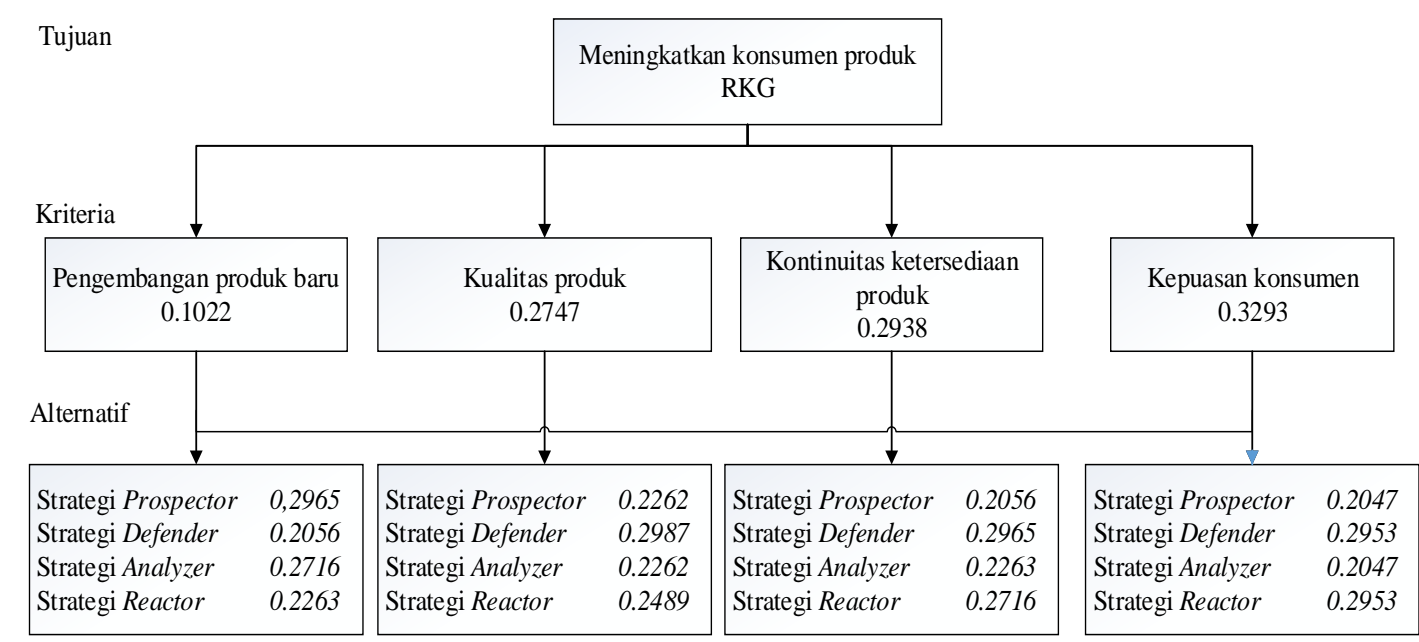

Gambar 2. Hasil akhir penilaian bobot keseluruhan

Gambar 2 menunjukkan bobot keseluruhan untuk kriteria dan bobot setiap alternatif terhadap setiap kriteria pada setiap hierarki. Perhitungan selanjutnya setelah mengetahui bobot alternatif terhadap setiap kriteria maka pengolahan selanjutnya adalah menghitung bobot alternatif secara keseluruhan. Hasil perhitungan bobot alternatif secara keseluruhan dapat dilihat pada Tabel 10.

Tabel 10. Hasil pembobotan alternatif keseluruhan

\begin{tabular}{lcc}
\hline Alternatif & Bobot & Peringkat \\
\hline Strategi prospector & 0,2203 & 4 \\
Strategi defender & $\mathbf{0 , 2 8 7 4}$ & 1 \\
Strategi analyzer & 0,2238 & 3 \\
Strategi reactor & 0,2685 & 2 \\
\hline
\end{tabular}

Alternatif strategi yang dipilih oleh responden dengan bobot tertinggi adalah strategi defender dengan bobot 0,2874. Sesuai dengan hasil perhitungan, maka untuk mencapai keempat kriteria pengembangan usaha alternatif pilihan yang memiliki nilai bobot paling tinggi adalah alternatif strategi defender. Strategi defender merupakan strategi yang lebih mengutamakan kestabilan pasar yang telah diciptakan. Upaya yang telah dilakukan untuk menjaga kestabilan pasar yang telah dimiliki adalah dengan menjadi supplier yang selalu memenuhi semua kebutuhan produk di pasar. Pemenuhan kebutuhan produk dilakukan dengan tetap menjaga kestabilan produksi produk terutama tempe higienis. Produksi dilakukan sesuai dengan kebutuhan, terutama jika akan mengikuti suatu pameran maka kapasitas produksi akan ditingkatkan sehingga kebutuhan konsumen dan kebutuhan event tetap dapat terpenuhi. Area pemasaran yang belum berkembang luas, dan jumlah produksi yang masih cenderung konstan menjadi pendukung bahwa strategi defender adalah alternatif strategi pilihan yang cocok untuk diterapkan dalam pengembangan unit usaha Rumah Tempe di Rumah Kedelai Grobogan dengan menjaga kestabilan pasar yang sudah dimiliki.

\section{KESIMPULAN DAN SARAN}

\section{Kesimpulan}

Terdapat empat kriteria yang dianggap penting dalam pengembangan unit usaha Rumah Tempe di Rumah Kedelai Grobogan yaitu pengembangan produk baru, kualitas produk, kontinuitas ketersediaan produk dan kepuasan konsumen. Kriteria disusun dengan mempertimbangkan beberapa faktor yang mempengaruhi pengembangan usaha. Faktor-faktor yang biasanya menjadi pertimbangan adalah faktor internal dan eksternal. Faktor internal terdiri dari aspek SDM, keuangan, produksi, pemasaran, serta teknologi. Sementara faktor eksternal terdiri dari kebijakan pemerintah, aspek sosial, budaya dan ekonomi, serta lingkungan. Berdasarkan penilaian responden, kriteria yang memiliki bobot tertinggi dalam strategi pengembangan usaha adalah kepuasan konsumen dengan nilai 0,3293 dan nilai CR 0,0070.

Hasil penilaian strategi alternatif pengembangan usaha Rumah Kedelai Grobogan adalah strategi prospector $(0,2203)$, strategi defender $(0,2874)$, strategi analyzer $(0,2238)$, dan strategi reactor $(0,2685)$. Strategi defender adalah prioritas strategi utama dalam strategi pengembangan unit usaha Rumah Tempe di Rumah Kedelai Grobogan. Karakteristik utama strategi defenderadalah lebih mengutamakan pada pencapaian kestabilan usaha. Strategi ini dapat dibangun dengan menciptakan kepuasan konsumen. Strategi defender yang menjadi strategi prioritas merupakan strategi yang tepat untuk mengembangkan unit usaha Rumah Tempe di Rumah Kedelai Grobogan. Penerapan strategi defender tidak membutuhkan tambahan sumberdaya, modal, dan SDM. Berbeda kondisinya jika menerapkan strategi prospector maka Rumah Kedelai Grobogan harus memiliki kesiapan dari segi sumberdaya, modal, dan SDM. Strategi defender cocok untuk mengembangkan Rumah Tempe karena unit ini telah memiliki konsumen tetap yang harus 
dipertahankan. Unit usaha lain di Rumah Kedelai Grobogan dapat memiliki strategi pengembangan usaha yang lain seperti unit seed center lebih cocok dikembangkan dengan strategi yang lebih agresif agar bisa mendapatkan konsumen awal karena penggunaan benih baru memerlukan perubahan dalam perilaku petani dan juga persaingan yang ketat dengan benih impor.

Beberapa kegiatan yang dapat mendukung pelaksanaan strategi defender adalah dilaksanakannya sistem penjaminan kualitas produk seperti implementasi HACCP ( (Hazard Analysis \& Critical Control Point) dan GMP (Good Manufacturing Practices) atau bahkan sertifikasi ISO untuk jangka panjangnya. Kegiatan lain yang dapat dilakukan adalah menciptakan produk yang sesuai dengan Standar Nasional Indonesia (SNI). Produk yang sesuai standar akan dapat meningkatkan kepuasan dan kepercayaan konsumen sehingga konsumen menjadi loyal terhadap produk dan pasar produk yang sudah ada dapat terus dipertahankan. Guna menjamin kualitas produk, maka perlu dilakukan proses Quality Control (QC) secara rutin dari mulai penyiapan bahan baku, proses produksi, proses penyimpanan, sampai pada proses distribusi hingga produk sampai pada konsumen. Strategi defender yang lebih fokus pada menjaga kestabilan usaha dapat didukung dengan kegiatan penguatan kerjasama dengan produsen bahan baku dan kelompok binaan karena tanpa adanya kerjasama yang baik dan kuat dapat berdampak pada terhentinya pasokan bahan baku dan produk.

\section{Saran}

Disarankan unit Rumah Kedelai Grobogan memiliki strategi pengembangan usaha yang efektif yaitu strategi yang lebih bersifat dinamis, sehingga perlu dilakukan evaluasi secara periodik untuk memperoleh alternatif strategi yang lebih baik. Evaluasi secara periodik dapat dilakukan dengan melibatkan pakar dari bidang terkait untuk memberikan masukan khususnya dinamika yang terjadi dalam lingkungan internal dan eksternal. Selain itu, perlu dilakukan penelitian lanjutan untuk menghitung jangka waktu penerapan strategi defender untuk pengembangan unit usaha Rumah Tempe di Rumah Kedelai Grobogan atau dengan menentukan ciri-ciri strategi defender tidak dapat diterapkan lagi sebagai strategi pengembangan unit usaha Rumah Tempe. Metode yang dilakukan dapat digunakan untuk menentukan strategi pengembangan unit usaha lain yang ada di Rumah Kedelai Grobogan.

\section{DAFTAR PUSTAKA}

Aydinoglu B. 2007. Innovation strategy measurement: development of an assessment tool to measure innovation strategy fitness of companies. [Thesis]. The Netherlands:Delft University of Technology.

Banbury CM dan Mitchell W. 1995. The effect of introducting important incremental innovations on market share and business survival. Strategic Management Journal. 16: 161-182.

Bjornali ES dan Ellingsen A. 2014. Factors affecting the development of clean-tech start-ups: A literature review. Energy Procedia. 58: 4350.

Campbell-Hunt C. 2000. What we have learned about generic competitive strategy? A metaanalysis. Strategic Management Journal. 21 (2):127-154.

Geels FW, Marko PH dan Jacobsson S. 2008. The dynamics of sustainable innovation journey. Technology Analysis \& Strategic Management. 20 (5): 521-536.

Gnjidic. V. 2014. Researching the dynamics of miles and snow's strategic typology. Journal of Contemporary Management Issues. 19 (1): 93-117.

Hekkert MP, Suurs RAA, Negro SO, Kuhlmann S, Smits REHM. 2007. Functions of innovation systems: A new approach for analysing technological change. Technological Forecasting \& Social Change. 74: 413-432.

Huberman AM dan Miles MB. 1994. Qualitative data analysis: An expanded sourcebook: Newbury Park. CA: Sage.

Leca B, Battilana J dan Boxenbaum E. 2008, Agency and Institutions: A Review of Insitutional Entrepreneurship. Harvard Business SchoolWorking papers No. 08-096

March JG. 1991. Exploration and exploitation in organizational learning. Organization Science 2(1): 71-87.

Mariano MJ, Fleming R, dan Fleming E. 2012. Factors influencing farmer's adoption of modern rice technologies and good management practices in the Philippines. Agricultural Systems. 110: 41-53.

Miles RE dan Snow CC. 2003. Organizational Strategy, Structure, and Process. Stanford, California (US): Stanford University Press.

Munizu M. 2010. Pengaruh fator-faktor eksternal dan internal terhadap kinerja usaha mikro dan kecil (UMK) di Sulawesi Selatan. Jurnal Manajemen dan Kewirausahaan. 12 (1): 2341.

Nabradi A dan Popp J. 2911. Economics of GM crop cultivation. Applied Studies in Agribusiness and Commerce. $5: 7-15$.

Porter ME. 1980. Competitive Strategy: Techniques for Analyzing Industries and Competitors. New York: Free Press.

Saaty TL dan Vargas LG. 2012. Models, Methods, Concepts dan Applications of the Analytic 
Hierarchy Process. New York: Springer Science+Business Media. ISSN 0884-8289

Shen L, Muduli K, dan Barve A. 2015. Developing a sustainable development framework in the context of mining industries: AHP Approach. Resources Policy. 46: 15-26.

Treacy M dan Wiersema F. 1993. Customer intimacy and other value disciplines. Harvard Business Review. 71: 84-94.

Zhang J, Di Benedetto CA, dan Hoenig S. 2009. Product development strategy, product innovation performance and the mediating role of knowledge utilization: evidence from subsidiaries in China.

Journal of

International Marketing. 17 (2): 42-58. 